\title{
Economic Security in the Conditions of Innovative Transformation of Economy
}

\author{
Tatiana G. Antropova ${ }^{1}$, Izida I. Ishmuradova ${ }^{2}$, Venera N. Minsabirova ${ }^{3}$, Farida S. Gazizova ${ }^{3} \&$ Ruslan R. \\ Temirbulatov $^{4}$ \\ ${ }^{1}$ Kazan National Research Technical University named after A. N. Tupolev, Kazan, Russia \\ ${ }^{2}$ Kazan Federal University, Naberezhnye Chelny, Russia \\ ${ }^{3}$ Kazan Federal University, Yelabuga, Russia \\ ${ }^{4}$ Kazan National Research Technological University, Kazan, Russia \\ Correspondence: Tatiana G. Antropova, Economic Theory Department, Kazan National Research Technical \\ University named after A. N. Tupolev, K. Marks Street 10, Kazan, Tatarstan, 420111, Russia. E-mail: \\ alfkazan@mail.ru
}

Received: October 24, 2014 Accepted: December 3, 2014 Online Published: December 18, 2014

doi:10.5539/res.v7n1p195 URL: http://dx.doi.org/10.5539/res.v7n1p195

\begin{abstract}
In article on the basis of theories of innovations and competitiveness the upward wave of a big cycle is preceded by activization of scientific discoveries, significant technical inventions and their implementation in production develops. The necessity of using the potential of the institutional environment of the Russian society on the formation of new institutions of development as a factor of increase of system effectiveness of economic security. It is proved that innovative transformation of economy demands increase in the state support of innovative institutes and the corresponding infrastructure of the institutional environment. Proposed to strengthen the innovative capacity of the country through the use of the potential of new institutes of development and the venture capital, which plays a system role in economy by continuous timely supply of innovations with necessary investments.
\end{abstract}

Keywords: economic security, institutional environment, new institutes of development, modernization of economy, innovative type of economic development, intellectual capital

\section{Introduction}

In formation of innovative economy of Russia more and more actual is becoming a need of development of the new directions of providing economic security in the conditions of increase of the internal and external risks connected with global social and economic processes.

These processes are followed by a qualitative transformation of the institutional environment, which is shown in redistribution of the property rights and in increase in specific weight of public sector, in an aggravation of contradictions between acting, the reformed and imported institutes. It causes considerable scientific interest for researchers of this problem (Antropova, 2010; Senchagov, 2013; Kuzminov et al., 2005; Polterovich, 2008).

Interests of economic security today demand creation of essentially new institutional environment focused on increase of competitiveness of economy through innovation, technological breakthrough, the development of nanotechnologies; an increase in its structure of the productions, corresponding to post-industrial technological way, modernization and innovative development as economic security is a condition promoting entry of the Russian economy into the course of the advancing development.

In article author's approach to research and creation of the coordinated system of institutes providing their effective interaction in the conditions of world social and economic instability and economic sanctions is applied. It is proved that the strategy of import substitution led nowadays demands increase in the state support of innovative development for providing economic security of the country. The state support of innovative activity is designated as set of tools and mechanisms of the state policy directed on strengthening of innovative activity. The instruments of the state support used within realization of innovative strategy are focused on formation of the legislative and legal base promoting innovative development, stimulation of demand for innovations, creation 
of national innovative system, wide use of the intellectual capital of the country.

\section{Materials and Methods}

The methodical device of research includes functional and structural aspects of system approach in relation to a problem of development of economic security. In determining the key problems of development are used: functional analysis; statistical analysis; the institutional analysis, situation analysis for identification of critical situations and ways to resolve them.

The necessity of developing a strategy, institutions and mechanisms for the use of intellectual property on the basis of public-private partnerships is proved. The intellectual capital is the main institute of development and a factor of development of the sixth technological way which accelerated development in Russia is insistently necessary in modern conditions of innovative transformation of economy.

\section{Results}

Unfortunately, in our country the institutional environment for a long time remained firm and its some modern optimization didn't change system characteristics of economy. In literature marked its components:

- asymmetry (multidirectional) actions of economic (market) and political institutions (political and legal institutions and, above all, the state) of development of the Russian economy;

- formalization (neutralization) of civil society institutions that can effectively restrict certain actions of the government, including in the case of rent extraction from staying at any level of government;

- corruption loyalty as the basis of system corruption;

- chronic lag of the legislation from economic realities, expansion of a zone of uncertainty and inadequacy of legislative and regulatory ensuring development processes of economic institutes;

- formation of "the double standard" and various rules of market game for different classes of participants, "dot" (selective) application of laws for political struggle and unfair competition that creates insurmountable obstacles both for formation of the favorable institutional environment, and for local institutional changes;

- negative interference of key institutes (for example, protection of the property rights and a financial system) that testifies to disinterest of the state in establishment of transparent rules and excludes possibility of effective regulation in separately taken segments.

Today it is clear that the market transformation of economy of Russia has brought to the society, which developed in the conditions of centralization and the state monopolism, set of institutes, are not peculiar to it before, but demanded by conditions of globalization economic relations and post-industrial development. Thus, reformers tried to apply "shock therapy" which ignored institutional heterogeneity of the maternal environment and institutes-grafts. In the conditions of low efficiency of the Russian economy efforts to create market institutes are poorly productive. Institutes actually work for fixing of export and raw model of development therefore capitalization of comparative advantages of the Russian economy, that is an intensification of investments in the sectors and branches possessing "potential competitiveness", including the enterprises with the knowledge-intensive production is necessary.

It provoked a spontaneous reaction of rejection from basic institutes and mobilization of their internal resources, including resources of monopolization of the economic relations. The result was a deep and prolonged systemic crisis. The original task of reforming consisted in an effective combination of the basic and introduced from the outside institutes. Why loan of institutes didn't ensure efficiency of an institutional matrix of the relations of economic security?

The concept of loan of institutions to some extent arbitrary, since patents and licenses for institutions aren't present so far. A problem essence - not in a normal exchange of institutions for money or other values, but in political, meaningful entry of the institution created in one economic system into other economic system. Russia had a historically short period of time to borrow and to implant in their nascent economic system of market type the mass of institutions. Such large-scale loan couldn't but create a problem of compatibility of institutes. We will allocate some vital issues of this aspect.

Firstly, it is an aspect of identity (an identical orientation and proportionality) of the borrowed institutions and the former (pre-reform) economic environment;

Secondly, an atrophy and full regeneration of institute when it is absolutely unclaimed in other economic and socio-cultural environment. Thus, regeneration of institute is fraught with that in it some destructive, mutant functions with destructive action on the recipient institutional environment are shown. Here is characteristic 
example of the transfer on the Russian soil of the western institutional model of bankruptcy in the early 90-ies of the XX century. Encountering the debris of the administrative system of management, it in only a few years turned into a complex of institutes of "shadow" redistribution of the property rights;

Thirdly, activization of alternative institutes and full rejection of the borrowed institutional model. The former institutional environment forms a peculiar negative demand for the institute introduced in it, finds in itself resources for active opposition to it and forms alternative institutes of these resources. For the last are characteristic not only "recognition" from the majority of economic entities, but also lower level of transactional expenses. Alternative institutes are more favorable. The alternative institute in a quantitative sense gets the best over borrowed, and in a qualitative sense forms an institutional "trap" for economic entities;

Fourthly, the institutional conflict - in this case the borrowed institute, adapting to a foreign environment, loses considerable part of its positive, functional and creative qualities, transforms ugly way, loses an ability to function effectively.

The major factors influencing success of import of institutions are degree and nature of congruence (compliance) of the dominating in the importing country informal rules and formal norms on the basis of which the imported institute functions. Existence of congruence allows to receive their convergence, rapprochement of a trend, trajectory of institutional development.

\section{Discussions}

This opportunity needs to be used, creating and strengthening new institutes - institutes of development (Dezhina, 2009). The institutes of development, which provide modernization of domestic economy and its transfer to an innovative trajectory of development, are as traditional: the financial, the tax, the investment, and new institutions that provide innovative development of system.

Institutionally, it is expedient in the interests of innovative transformation of economy to reinforce our leading industry with measures of organizational support of domestic innovations. Currently, certain positive role began playing the Russian Venture Company (RVC) and the Russian Investment Fund of Information and Communication Technologies (RIFICT), which have the main task of supporting the venture and innovative business. RVK has to provide participation of the state in mutual investment funds which capital can be used for financing of campaigns in the sphere of telecommunications, biotechnologies, medicine, power. It is supposed that it will allow to increase a share of innovative production of internal industrial sales up to $15 \%$. Today this share is low: in Russia only $8-10 \%$ of innovative ideas and hi-tech products, while, for example, in the USA $-62 \%$, in Japan $-95 \%$ are on average used today. The domestic factory science carries out only $6 \%$ of scientific researches, and in the companies of EU countries- $65 \%$, in Japan-71\%, in the USA $-75 \%$. (Voronin, 2009).

The major factors, which are, still, constraining innovative activity in Russia are shortage of financial resources and insufficient level of the state support. During the last decades went funds within 1\% of GDP for financing of basic and applied scientific researches. On this indicator Russia, which put forward an ambitious task - creation of the competitive, based on intelligence and knowledge of economy, i.e. such economy where the main engine are not rates of exploitation of natural resources, but the ideas, inventions and ability to implement them faster than others in everyday life - so far lags behind the developed countries of the world more than twice (Fig. 1) And that a half of expenses on science in the developed countries is supported by the state is characteristic.

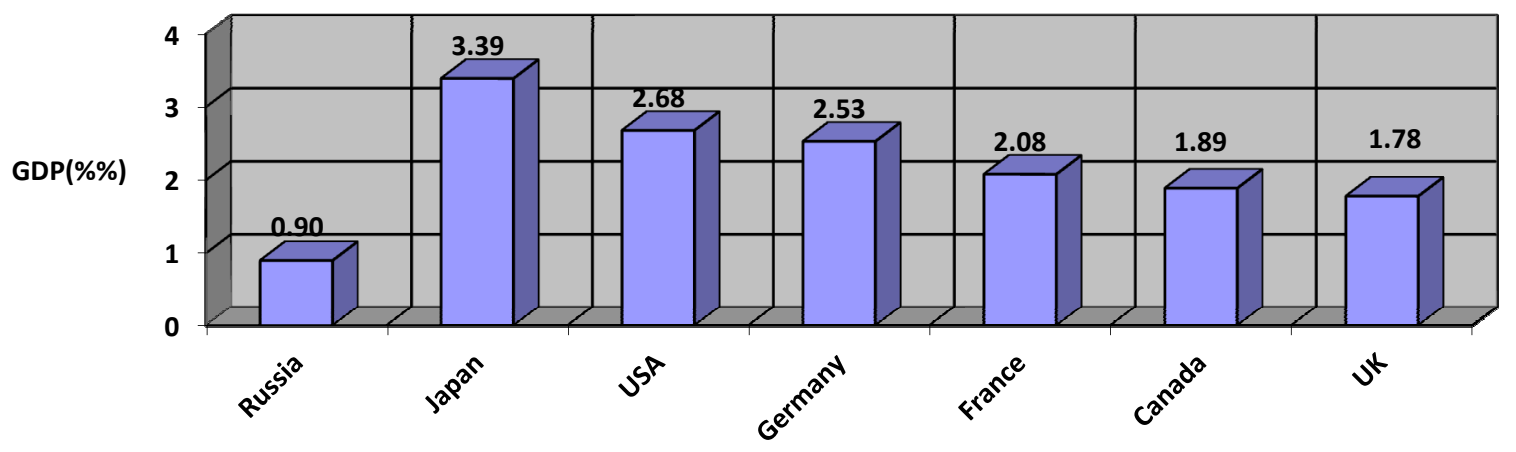

Figure 1. Costs of financing of scientific researches (A share in $\% \%$ of GDP) 
In the Presidential Decree (No. 599 of 2013) "About measures for realization of a state policy in science and education" the task of increase by 2015 of internal costs for researches and development to $1.77 \%$ of a gross domestic product with increase in a share of educational institutions of higher professional education in such expenses to $11.4 \%$ is set.

\section{Conclusion}

The paramount task in article designated need of creation of a network of institutes of development - system which purposefully would work for national industrial and technological transformation of economy, in other words, on formation of national innovative system.

Substantiates the strategy of use of intellectual property as bases for increase of competitiveness and efficiency of economy of Russia, institutes of development, the intellectual capital and strengthening of technological safety in the conditions of application of economic sanctions. Orientation to import of innovations does development of the Russian economy vulnerable and dependent on an external environment. Innovative business demands state regulation and, first of all, where the innovative enterprises are localized and where their effects are obvious.

Need is proved:

- of strengthening of support of scientific and inventive activity, stimulation of authors of scientific discoveries, inventions, subjects of copyright and related rights;

- of use of resources of integrated partnership within BRICS for development of joint innovative programs and projects and fight against supermonopolization of the world market of the intellectual capital (in 2012 more than $98 \%$ of the income from intellectual property appropriated the countries with the high income, including more than 51\% - the USA) (Abramov, 2013). The considerable attention has to be paid to creation of the coordinated system of institutes providing effective interaction of scientific institutions, implementation structures today (Peters, 2006).

Such approach develops the economic theory of institutes in the direction of an assessment of extent of their influence on parameters of innovative development and providing economic security of the country.

The practical importance of research consists in possibility of use of the provisions offered in the project and methodical approaches to development of the mechanism of the state support of innovative development of all forms of managing by federal and regional authorities at realization of innovative policy and programs of innovative development.

In Decree of the Russian President the No. 599 the central directions of a state policy in this sphere are defined:

- formation of specialized venture funds for the purpose of the direction of the venture capital in the scientific and technical and innovative environment;

- development of forms and methods of the state support of subjects of innovative activity;

- creation of the innovative infrastructure presented by subjects of innovative activity of the state, interindustry, branch and regional levels.

\section{Recomendations}

Strengthening of innovative institutes and the corresponding infrastructure of the Russian economy, restructuring of its institutional environment, application of special institutes of development, formation of innovative model of the Russian economy for activization of all opportunities of providing economic security of the country.

Use of financial instruments of support of innovative economy represented by banks and agencies of development, export-import banks, export and insurance economic debt agencies, finance corporations, investment funds, venture funds, sovereign funds, etc. is necessary. In the same purposes it is necessary to use also non-financial structures: special economic zones, technopolises, science and technology parks, scientific and implementation innovative centers and agencies, scientific funds, industrial unions, educational and expert and analytical centers, various corporations.

Experience of Tatarstan where the investment component of republican economy always is in the center of attention that allows to develop effectively industrial branches is interesting in this plan, the share of the innovation-active enterprises in the republic makes 12.5\% (on average across the Russian Federation-9.0\%), act 14 science and technology parks, 1 technopolis, 5 business incubators, 6 investment and venture funds (Results of development of the industry, consumer market and foreign economic activity of the Republic of Tatarstan in 2013, 2014). Now in the republic the package of measures directed on creating favorable conditions for activization of innovative and 
investment activity for economic recovery, increase of production efficiency and the solution of social tasks is realized. Involvement of the largest world leaders in all priority activities as anchor residents of the techno and industrial parks created and already operating in the republic becomes the main vector of work.

It is possible to strengthen innovative opportunities of the country, using the potential of the venture capital which plays a system role in economy, acting as a link between investors and the innovative companies needing capital investments. (Antropova, 2014). Having focused attention on restructurings of the institutional environment, on wide use of institutes of development of economy it is possible to create conditions for activization of all opportunities of strengthening of economic security of the country.

\section{References}

Abramov, V. L. (2013). Analisis and Forecast of Increasing the Role of Science and Technology in the Development and Competiteveness of the Russian Economy. Partnership of Civilizations. International scientific-practical journal, 4, 94-101.

Antropova, T. G. (2010). Institutional design of economic security (p. 224). Kazan.

Antropova, T. G. (2014). Institutes of development of economic security in formation of innovative economy of Russia (p. 10). Kazan science.

Dezhina, I. (2013). Institutes of development: What is known about their efficiency? Innovations, 126, 4. Retrieved March 13, 2014, from http://trv-science.ru/2013/04/09/instituty-razvitiyachto-izvestno-ob-ikh-ehffektivnosti

Kuzminov, Y., Radayev, V., Yakovlev, A., \& Yasin, E. (2005). Institutes: From loan to cultivation (experience of the Russian reforms and possibility of cultivation of institutional changes). Economy Questions, 5, 9-14.

Peters, S. (2006). National systems of innovation: Creating high-technology industries (p. 267). New York.

Polterovich, V. (2008). Modernization strategy, institutes and coalitions. Economy Questions, 4, 4-24.

Results of development of the industry, consumer market and foreign economic activity of the Republic of Tatarstan in 2013. (2014). Tasks for 2014 (p. 86). Kazan: Ministry of the industry and trade of the Republic of Tatarstan.

Senchagov, V. K. (2013). Innovative transformations as an imperative of a sustainable development and economic security of Russia (p. 684). Moscow.

Voronin, Y. M. (2009). Russia and world economic crises. Free thought, 11, 5-7.

\section{Copyrights}

Copyright for this article is retained by the author(s), with first publication rights granted to the journal.

This is an open-access article distributed under the terms and conditions of the Creative Commons Attribution license (http://creativecommons.org/licenses/by/3.0/). 